\title{
PERAN FORUM KERUKUNAN UMAT BERAGAMA (FKUB) DALAM PEMBINAAN KERUKUNAN HIDUP BERAGAMA DI LUWU TIMUR
}

\author{
${ }^{1}$ Kaharuddin, ${ }^{2}$ Muh. Darwis \\ 1,2Institut Agama Islam Negeri Palopo \\ Jl. Agatis Balandai Kota Palopo, Sulsel, Indonesia \\ E-mail: kaharuddin@iainpalopo.ac.id
}

\begin{abstract}
This study aims to describe the diversity of the community and the role of FKUB in maintaining the harmonization of the religious harmony trilogy of East Luwu people. Data were obtained through interviews with administrators of the FKUB East Luwu, religious leaders from each religion in the regency. East Luwu, Ministry of Religion East Luwu and ordinary people. The results of this study indicate that the people of East Luwu Regency are very diverse because they consist of various tribes, races, cultures and religions. But that pluralism also made East Luwu people very tolerant. The East Luwu Religious Harmony Forum (FKUB) is very strategic in fostering and maintaining harmonious harmony of life in the community, nation and state, especially in maintaining the harmonization of religious harmony, between religious communities, and between religious life with the Government.
\end{abstract}

Keywords: Conjoining, Construction, FKUB, Religious

\begin{abstract}
Abstrak
Penelitian ini bertujuan untuk mengetahui gambaran keberagaman masyarakat dan peran FKUB dalam memelihara harmonisasi trilogi kerukunan beragama masyarakat Luwu Timur. Data diperoleh melalui wawancara dengan pengurus FKUB Kab. Luwu Timur, tokoh agama dari masing-masing agama yang ada di Kab. Luwu Timur, Kementerian Agama Kab. Luwu Timur dan masyarakat biasa. Hasil penelitian ini menunjukkan bahwa masyarakat Kabupaten Luwu Timur sangat majemuk karena terdiri dari berbagai suku, ras, budaya dan agama. Namun kemajemukan itu juga yang menjadikan masyarakat Luwu Timur sangat toleran. Forum Kerukunan Umat Beragama (FKUB) Luwu Timur sangat strategis dalam membina dan memelihara harmonisasi kerukunan hidup bermasyarakat, berbangsa dan bernegara, terutama dalam memelihara harmonisasi kerukunan hidup beragama, antar umat beragama, dan antar hidup beragama dengan Pemerintah.
\end{abstract}

Kata Kunci: Beragama, FKUB, Kerukunan, Pembinaan

\section{PENDAHULUAN}

Bangsa Indonesia terdiri atas berbagai macam suku, bahasa, budaya dan agama. Keberagaman suku, bahasa, budaya dan agama pada hakikatnya justru memperkaya khasanah budaya bangsa. Salah satu wujud budaya Indonesia tersebut adalah budaya spiritual yang berakar pada kepercayaan terhadap Tuhan Yang Maha Esa, yang pada dasarnya adalah warisan leluhur budaya 


\section{2 | Kaharuddin, Muh. Darwis}

bangsa. Kepercayaan terhadap Tuhan Yang Maha Esa sebagai salah satu aspek warisan budaya bangsa (budaya spiritual) secara realistis masih hidup dan berkembang serta dihayati oleh sebagian masyarakat Indonesia.

Secara historis sosiologis, agama merupakan suatu fakta, data, dan fenomena yang bisa dikaji secara ilmiah. Selain itu, agama juga menjadi kebutuhan yang mendasar bagi eksistensi manusia di dunia. Hal ini disebabkan oleh karakteristik manusia yang membutuhkan, tentu secara fitrah akan keberadaan Yang Suci. Kebutuhan mendasar itu lalu terejawantah dan dibentuk dalam suatu sistem dengan berbagai perangkat aturan yang ada di dalamnya, yang kemudian disebut sebagai agama. Pengaruh akan kehadiran agama ini ikut serta dalam membentuk serta menentukan pola berfikir dan sikap hidupnya.

Masyarakat yang beragama baik muslim maupun non-muslim seringkali bersikap eksklusif, mereka merasa bahwa hanya ajaran agama merekalah yang dapat membawa dan memberikan keselamatan. Agama mengajarkan kebenaran kepada setiap pemeluknya, dan membawa misi keselamatan bagi seluruh umatnya. Begitu pula tidak satupun agama di dunia ini yang mengajarkan atau menganjurkan kepada pemeluknya untuk melakukan kerusuhan, saling memusuhi, apalagi saling membunuh.

Hidup bermasyarakat tentunya tahu bahwasanya pemahaman terhadap agama tidak semunya menyeluruh, hal ini biasa disebut dengan sifat agama orang awam. Keberagamaan kebudayaan agama yang turun- temurun artinya dia hanya meyakini apa yang diajarkan oleh nenek moyang mereka, tanpa mengkaji lagi apakah kajian itu benar atau salah serta mereka tidak ada pikiran untuk memperdalam ajaran warisan tersebut, hal yang terpenting mereka lakukan adalah bagaimana mereka bisa melestarikan apa yang diajarkan oleh nenek moyang mereka, tanpa mengurangi sedikitpun.

Kabupaten Luwu Timur merupakan wilayah yang masyarakatnya majemuk dan pluralis, yang terdiri dari berbagai suku, bahasa, budaya dan agama. Agama yang dimaksud adalah Islam, Kristen Protestan, Katolik, Hindu. Karena kemajemukannya maka perlu hidup secara rukun. Kerukunan yang dimaksud adalah trilogi. Dan Untuk menata hubungan kerukunan tersebut maka diperlukan sebuah forum kerukunan antar umat beragama, yaitu FKUB Kab. Luwu Timur. FKUB ini berperan sebagai forum kerukunan umat beragama dalam melakukan pembinaan, penyampaian, dan penyeruan nilainilai ajaran agama sesuai ajaran masing-masing.

Penelitian merupakan penelitian normatif yang masih membutukan penelitian-penelitian lain yang relevan dengan penelitian peneliti, seperti sebagai berikut. Pertama, pada riset kesarjanaan yang ditulis oleh Arif 
Budianto, yang berjudul Kerukunan Umat Beragama (Studi Hubungan Pemeluk Islam dan Kristen di Relokasi Turgo Sleman Yogyakarta) ${ }^{1}$. Penelitian ini mengulas tentang hubungan kehidupan keberagamaan di Relokasi Turgo berjalan sangat dinamis semua itu terwujud dalam bentuk gotong royong, pembangunan sarana pendidikan bahkan pembangunan rumah ibadah. Serta terwujud dalam penyatuan ritual agama tradisi lokal. Meski demikian, hubungan yang begitu harmonis tersebut sempat renggang. Halini disebabkan adanya isu kristenisasi yang dihembuskan oleh pihak-pihak tertentu. Namun kondisi ini cepat mendapat respon dari tokoh agama, mereka mengadakan dialog dan masyarakatpun dapat memahami, dari proses memahami tersebut lahir sifat toleransi. Kedua, Penelitian oleh Susanti yang berjudul "Kerukunan di Pura Eka Darma Kasihan Bantul (Studi Kerukunan Multikultural)"2, Penelitian ini membahas tentang kerukunan bukan didasari atas sikap sinkritis yang dibuat-buat, melainkan suatu kondisi bahwa semua golongan agama bisa hidup bersama-sama tanpa mengurangi hak masing-masing umat, untuk melaksanakan kewajiban. Selain itu penelitian ini juga lebih fokus membahas tentang peran Pura Eka Dharma dalam mewujudkan kerukunan multikultural dengan berpijak pada konsep-konsep yang ditawarkan oleh Mukti Ali.

\section{METODE}

Penelitian ini dilaksanakan Kabupaten Luwu Timur Provinsi Sulawesi Selatan. Adapun subjek penelitian ini adalah Forum Kerukunan Umat Beragama (FKUB), pengurus FKUB Kab. Luwu Timur, tokoh agama dari masing-masing agama yang ada di Kab. Luwu Timur, Kementerian Agama Kab. Luwu Timur dan Masyarakat biasa. Penelitian ini dilaksanakan pada bulan Mei sampai Agustus tahun 2018. Teknik pengumpulan da ta yang digunakan adalah observasi, wawancara dan dokumentasi sedangkan analisis data dilakukan dengan pengujian keabsahan data yaitu Triangulasi sumber dan Triangulasi Metode dengan membandingkan pengamatan dengan pengamatan selanjutnya, dan membandingkan pengamatan dengan hasil wawancara.

1 Arif Budianto, Kerukunan Umat Beragama (Studi Hubungan Pemeluk Islam dan Kristen di Relokasi Turgo Sleman Yogyakarta), Fakultas Ushuludin UIN Sunan Kalijaga, Yogyakarta, 2006.

2 Sri Puji Lestari, "Hubungan Antar Umat Beragama di Lingkungan Masyarakat Wihara Jina Dharma Sradha Desa Siraman Kecamatan Wonosari Kabupaten Gunung Kidu" (Fakultas Ushuludin UIN Sunan Kalijaga, 2009). 


\section{GAMBARAN KEBERAGAMAN MASYARAKAT}

Kabupaten Luwu Timur masyarakatnya sangat majemuk karena terdiri dari berbagai suku,ras,budaya dan agama. Tetapi kemajemukan itu juga masyarakat Luwu Timur sangat toleran. Hal dikemukakan Kepala kemeterian Agama Luwu Timur, ia mengemukakan:

"Masyarakat disini (Luwu Timur) majemuk, bahkan semua suku terdapat di Luwu Timur. Mereka datang dari berbagai daerah dengan membawa masing ciri khasnya. Tapi kelebihannya mereka fokus pada masing-masing urusannya. Dia tidak urus atau mengusik urusan orang lain atau pemeluk agama yang satu dengan pemeluk agama lainnya. ${ }^{3}$

Salah satu keunikan masyarakat Luwu Timur karena tidak saling mengusik antara satu dengan lainnya dalam berinteraksi sosial terutama dalam urusan yang terkait dengan keagamaan. Hal ini merupakan keunikan tersendiri dibanding dengan daerah lain.

Menurut Harun, keragaman masyarakat Luwu Timur sangat majemuk dari segi agama, suku dan budaya. Dan sejauh ini keragaman dipahami sebagai sebuah kekayaan sehingga tidak menimbulkan konflik. Cara menjaga keharmonisan antara umat beragama di Luwu Timur ialah Silaturrahmi, menjalin harmonisasi, dan kordinasi, rasa saling menghargai antara satu dengan yang lainnya. ${ }^{4}$

Dari wawancara tersebut dapat dipahami bahwa masyarakat Luwu Timur adalah masyarakat yang majemuk baik dari segi agama, budaya dan suku. Bahkan boleh dikatakan bahwa semua suku terdapat di daerah Luwu Timur. Dari keragaman tersebut tetap terjaga kerukunan dan harmonisasi dalam hidup bermasyarakat. Hal ini disebabkan karena masyarakat memahami bahwa keragaman itu adalah bahagian dari kekayaan kita yang harus dirawat dan dijaga dengan baik. Dan untuk menjaga kekayaan tersebut harus dibingkai dengan menjalin silaturrahmi yang dibangun di atas dasar kordinasi dan saling menghargai antara satu dengan yang lainnya. Demikian juga halnya apa yang dikemuakakan oleh Sumarni S., bahwa masyarakat Luwu Timur adalah masyarakat hidup rukun dan damai, tidak menimbulkan konflik dan tetap harmonis. Hal ini karena masyarakat saling menghormati dan menghargai perbedaan masing-masing. 5

${ }^{3}$ H. Abu Bakar, Kepala Kementerian Agama Luwu Timur. Wawancara. Di Rumah Jabatan Kemeterian Agama Luwu Timur., 1 Oktober 2018.

${ }^{4}$ Harun, Kasi Bimas Kristen. Wawancara di ruang kerja Kantor Kemeterian Agama Luwu Timur, 20 September 2018.

5Sumarni S., Staf Kementerian Agama Luwu Timur. Wawancara., 1 Oktober 2018. 
Dari keterangan tersebut dipahami bahwa keragaman masyarakat Luwu Timur tetap terpelihara dan mereka hidup rukun dan damai. Hal ini disebabkan karena mereka saling menghargai perbedaan diantara mereka. Mereka berbeda tapi tetap satu dalam hidup bermasyarakat. Selanjutnya Mardan mengemukakan bahwa Keragama masyarakat Luwu Timur tetap hidup rukun dan Harmonis. Tidak menimbulkan konflik. Hal ini terwujud karena mereke saling hargai dan menghormati. ${ }^{6}$

Dari penjelasan ini menunjukkan bahwa masyarakat Luwu Timur adalah masyarakat yang memelihara toleransi yang sangat bagus dalam hidup bermasyarakat berbangsa dan bernegara. Hal ini dipahami bahwa betapapun kemajemukan masyarakat tetapi memiliki toleransi yang baik maka harmonisasi didalam bermasyarakat akan terjamin dengan sendirinya.

Tabel 5.1 Jumlah Penduduk Menurut Agama Tahun 2017

\begin{tabular}{|c|l|c|c|c|c|c|c|}
\hline NO & \multicolumn{1}{|c|}{ KEC. } & Islam & Kristen & Katholik & Hindu & Khonghucu & Kepercayaan \\
\hline 1 & Mangkutana & 12.522 & 9.248 & 1.060 & 7 & 0 & 0 \\
\hline 2 & Nuha & 19.501 & 3.842 & 473 & 132 & 0 & 0 \\
\hline 3 & Towuti & 30.469 & 7.061 & 1.195 & 133 & 0 & 0 \\
\hline 4 & Malili & 38.238 & 2.277 & 231 & 545 & 0 & 0 \\
\hline 5 & Angkona & 15.937 & 1.781 & 590 & 6.518 & 0 & 0 \\
\hline 6 & Wotu & 28.855 & 2.097 & 549 & 1.862 & 0 & 0 \\
\hline 7 & Burau & 29.116 & 4.933 & 399 & 1.324 & 0 & 0 \\
\hline 8 & Tomoni & 21.325 & 4.462 & 327 & 30 & 0 & 0 \\
\hline 9 & $\begin{array}{l}\text { Tomoni } \\
\end{array}$ & 5.546 & 2.961 & 466 & 4.542 & 0 & 0 \\
\hline 10 & Kalena & 8.932 & 1.560 & 91 & 1.444 & 0 & 0 \\
\hline 11 & Wasuponda & 13.066 & 7.279 & 1.417 & 38 & 0 & 0 \\
\hline & TOTAL & 223.507 & 47.501 & 6.798 & 16.575 & 0 & 0 \\
\hline
\end{tabular}


Tabel 5.2. Rumah Ibadah Tahun 2017 Kabupaten Luwu Timur

\begin{tabular}{|c|c|c|c|c|c|c|c|}
\hline \hline No. & $\begin{array}{c}\text { Kabupaten / } \\
\text { Kota }\end{array}$ & Masjid*) & Geraja & $\begin{array}{c}\text { Geraja } \\
\text { Katolik }\end{array}$ & $\begin{array}{c}\text { Pura/ } \\
\text { Hindu }\end{array}$ & $\begin{array}{c}\text { Vihara / } \\
\text { Budha }\end{array}$ & $\begin{array}{c}\text { Kelenteng } \\
/ \\
\text { Konghucu }\end{array}$ \\
\hline 1 & Burau & 55 & 30 & 2 & 5 & 0 & 0 \\
\hline 2 & Wotu & 35 & 19 & 1 & 6 & 0 & 0 \\
\hline 3 & Tomoni & 28 & 22 & 2 & 0 & 0 & 0 \\
\hline 4 & $\begin{array}{c}\text { Tomoni- } \\
\text { Timur }\end{array}$ & 9 & 15 & 3 & 13 & 0 & 0 \\
\hline 5 & Angkona & 61 & 15 & 3 & 19 & 0 & 0 \\
\hline 6 & Malili & 44 & 5 & 5 & 3 & 0 & 0 \\
\hline 7 & Towuti & 18 & 14 & 1 & 0 & 0 & 0 \\
\hline 8 & Nuha & 14 & 12 & 1 & 1 & 0 & 0 \\
\hline 9 & Wasuponda & 21 & 36 & 5 & 0 & 0 & 0 \\
\hline 10 & Mangkutana & 31 & 54 & 7 & 0 & 0 & 0 \\
\hline 11 & Kalena & 22 & 16 & 3 & 9 & 0 & 0 \\
\hline & TOTAL & 338 & 238 & 33 & 56 & 0 & 0 \\
\hline
\end{tabular}

\section{EKSISTENSI FKUB DI LUWU TIMUR}

Menurut H. Mando bahwa masyarakat Luwu Timur telah menyadari bahwa harmonisasi dan kerukunan itu sangat dibutuhkan dalam hidup bermasyarakat berbangsa dan bernegara. Mereka telah banyak belajar pada sejarah dimasa lalu. Mereka menyadari bahwa bercerai berai itu sangat tidak menguntungkan bagi kehidupan kita semua. Itulah sebabnya mereka sangat resfek terhadap eksistensi FKUB selama ini. ${ }^{7}$ Senada dengan itu juga Muhammad Guntur Hafid, M.Pd. mengemukakan bahwa Eksistensi FKUB Luwu Timur sangat dibutuhkan Pemerintah dan masyarakat Luwu Timur. Karena peran FKUB dialah selalu terdepan jika ada gesekan-gesekan yang terjadi di masyarakat. Mereka para pengurus FKUB adalah tokoh yang mewakili keragaman bermasyarakat di Luwu Timur. ${ }^{8}$

Forum Kerukunan Umat Beragama (FKUB) Luwu Timur sangat strategis dalam membina dan memelihara harmonisasi kerukunan hidup bermasyarakat, berbangsa dan bernegara, terutama dalam memelihara harmonisasi kerukunan hidup beragama, antar umat beragama, dan antar hidup beragama dengan Pemerintah. Harmonisasi dan kerukunan seperti itu

7 H. Mando, Pengurus Forum Komunikasi Kerukunan Umat Beragama (FKUB) Luwu Timur. Wawancara. Kantor FKUB Luwu Timur, 2 Oktober 2018.

${ }^{8}$ Guntur, Kepala Kesbangpol Luwu Timur. 
terbangun karena salah satu komponen di dalamnya memiliki peran dan andil yang sangat besar adalah Forum Kerukunan Umat Beragama. Karena orang orang yang terlibat dalam FKUB didengar dan ditokohkan oleh masyarakat. Sehingga jika ada masalah bisa terselesaikan dengan baik.

Menurut Ketua FKUB Luwu Timur H. Ardiansyah, ${ }^{9}$ mengemukakan analoginya terkait dengan eksistensi FKUB Luwu Timur bahwa :

FKUB Luwu Timur memang secara lahir tidak nampak kegiatannya karena kita memang seperti Magnet dan Aliran Listrik cara kerjanya, tidak nampak tapi menggerakan semua lini sebagaimana aliran listrik yang mengarahkan semua kegiatan yang dilakuan oleh manusia. Jadi FKUB tidak sama cara kerjanya dengan lainnya yang jelas dan nampak apa yang mereka lakukan. Tetapi hampir semua kegiatan kemasyarakatan FKUB selalu hadir bersama dengan Pemerintah setempat dan masyarakat.

Lebih lanjut dia mengemukakan bahwa, cara kerja FKUB Luwu Timur selama ini adalah menyelesaikan masalah terdahulu lalu kemudian disusul dengan rapat para pengurus FKUB tersebut dalam membicarakan langkah langkah yang strategis dilakukan untuk menyelesaikan masalah tersebut.

Kerukunan umat beragama di Luwu Timur (Lutim) selama ini dikenal masih tetap terjaga. Untuk itu, Bupati Luwu Timur, Ir H Muh Thorig Husler, yang didampingi Wakil Bupati (Wabup) Irwan Bahri Syam, memberikan apresiasi pada saat mengukuhkan pengurus Forum Kerukunan Umat Beragama (FKUB) Kabupaten Luwu Timur periode 2017-2022, di Aula Rumah Jabatan Bupati LuwuTimur. ${ }^{10}$ Husler menyebutkan, salah satu tujuan dibentuknya FKUB, adalah sebagai wadah komunikasi antar umat beragama yang pembentukannya berdasarkan usul Majelis agama dan masyarakat setempat. Selain itu juga, FKUB berperan sebagai mitra konsultatif Pemerintah Daerah dalam memberikan rekomendasi kebijakan kepada kepala daerah, terkait dengan kondisi kerukunan umat beragama di daerah. "Seperti kita ketahui bersama, bahwa masyarakat Bumi Batara Guru ini merupakan masyarakat yang beragam suku, agama, ras dan golongan. Hal ini tentu sangat penting bagi setiap lapisan masyarakat untuk menjaga kerukunan beragama, karena itu FKUB sangat mutlak diperlukan," ujar Husler. ${ }^{11}$

Lebih lanjut disampaikan Husler, dengan kehadiran FKUB di daerah ini memang telah dirasakan manfaatnya, terutama dalam mengantisipasi terjadinya gesekan dan konflik antar umat beragama. Oleh karenanya, Husler

${ }^{9}$ H. Ardiansyah, Ketua Forum Kerukunan Umat Beragama Luwu Timur. Wawancara. Di Kantor FKUB Luwu Timur, 2 Oktober 2018.

10 “TEKAPE.com,” Berita, Pengukuhan FKUB Luwu Timur, tekape.com. diakses 26 Mei 2018 11 “TEKAPE.com.” 
berharap dengan adanya FKUB dapat semakin meningkatkan peranan dan kontribusinya sekaligus bekerjasama aktif dalam menjaga suasana kondusif di Kabupaten Luwu Timur seperti yang sudah terjadi selama ini. ${ }^{12}$

Sebelumnya, Ketua FKUB Luwu Timur Drs. H Ardias Bara, dalam sambutannya mengatakan, fungsi dari FKUB sebagai penyerap, penghimpun dan penyalur aspirasi umat beragama dan ormas keagamaan, penciptaan iklim yang kondusif bagi keamanan dan kenyamanan umat beragama dalam melaksanakan ibadahnya serta menciptakan ekonomi umat dalam rangka peningkatan kesejahteraan. "Salah satu tugas dan fungsi dari FKUB dengan menggelar dialog bersama pemuka agama dan tokoh masyarakat, menampung aspirasi ormas keagamaan serta masyarakat dalam bentuk rekomendasi sebagai bahan kajian bagi pemerintah," ujar Ardias Bara. ${ }^{13}$

Dalam pengukuhan tersebut, Wakil Bupati Luwu Timur, Irwan Bachri Syam menjabat sebagai Dewan Penasehat, sementara Drs. H. Ardias Bara terpilih kembali menjadi Ketua FKUB Kabupaten Luwu Timur bersama Wakil Ketua Pdt Yorim R Karoma, I Wayan Sudarsana, Pastor Lukas Paliling, Drs M Ahmad Said. ${ }^{14}$ Sementara Sekretaris FKUB dijabat Drs. H. Muh Tahir, Wakil Sekretaris H. Muh Yunus. Sebagai anggota H Dandu Kasim, HA Mursaha Djunaid, I Gede Sudarsana, H Hisbullah, Pdt Lukas Paonganan, Pdt Jhon Daud, Yohennes Djoni, Harun, H.M Syahruddin, M Ali Usman untuk periode 2017 2022. Turut dihadiri Kapolres Luwu Timur AKBP Parajohan Simanjuntak, Ketua DPRD Luwu Timur, Amran Syam, Kejari Malili, Ketua MUI Luwu Timur, H Azis Rajmal, Asisten Pemerintahan, Dohri As'ari, Kepala SKPD, Camat, tokoh masyarakat, tokoh agama, ormas agama serta undangan lainnya.

Dalam kegiatan itu, juga diadakan penandatanganan Ikrar Forum Kerukunan Umat Beragama dengan tekad menjaga keutuhan negara kesatuan Republik Indonesia dan memelihara kerukunan umat beragama Luwu Timur. ${ }^{15}$

12 “TEKAPE.com.”

13 Ardias Bara, Pengurus Forum Komunikasi Kerukunan Umat Beragama (FKUB) Luwu Timur. Wawancara. Kantor FKUB Luwu Timur, 2 Oktober 2018.

14 Bara.

15 Bara. 


\section{PERAN FORUM KERUKUNAN UMAT BERGAMA (FKUB) DI LUWU TIMUR DALAM MEMELIHARA HARMONISASI TRILOGI KERUKUNAN HIDUP BERAGAMA MASYARAKAT LUWU TIMUR.}

Peran Forum Kerukunan antar umat bergama (FKUB) dalam memelihara harmonisasi trilogi kerukunan hidup beragama masyarakat Luwu Timur dapat dilihat sebagai berikut:

Harun mengemukakan bahwa: FKUB Luwu Timur sangat berperan aktif dalam menjalin harmonisasi dan saling menghargai. Mendor ong umat beragama dalam hal saling menghormati dalam perayaan hari-hari besar keagamaan dan menongkatkan silaturrahmi. Saling bekerjasama, saling mendorong dan bersinergi dalam upaya menciptakan kerukunan umat beragama.

Pertama-tama peran strategis FKUB dalam pelaksanaan PBM khususnya dan kerukunan umat beragama pada umumnya terlihat dalam tugas FKUB sebagaimana diatur dalam PBM Pasal 9 ayat (1) dan (2), yaitu sebagai berikut:1.) Melakukan dialog dengan tokoh agama dan masyarakat; 2.) Menampung aspirasi ormas keagamaan dan aspirasi masyarakat. 3 . Menyalurkan aspirasi ormas keagamaan dan masyarakat dalam bentuk rekomendasi sebagai bahan kebijakan kepala daerah.; 4.) Melakukan sosialisasi peraturan-perundangan dan kebijakan di bidang keagamaan yang berkaitan dengan kerukunan umat beragama dan pemberdayaan masyarakat; 5. Memberikan rekomendasi tertulis atas permohonan pendirian rumah ibadah.

Selain lima butir tugas strategis yang telah termuat dalam PBM di atas, FKUB Propinsi dan Kabupaten/Kota juga memiliki sedikitnya tiga tugas strategis lain bagi pemeliharaan kerukunan umat beragama, yaitu: 1). Tugas deteksi dini dan pemetaan gangguan kerukunan umat beragama. FKUB diharapkan dapat mengidentifikasi potensi gangguan kerukunan umat beragama secara dini dengan memetakan gangguan kerukunan yang telah terjadi di daerah dan dengan mengidentifikasi kemungkinan pengaruh gangguan kerukunan di daerah lain terhadap daerahnya, dan mengidentifikasi pengaruh faktor-faktor non-keagamaan (politik, ekonomi, kesukuan, kedaerahan, dll.) yang dapat mempengaruhi kerukunan antar umat beragama. 2). Tugas meredam dan mencari solusi terhadap gangguan kerukunan umat beragama. Apabila terjadi suatu gangguan kerukunan umat beragama, sekecil apapun, maka FKUB diharapkan dapat membantu pemerintah daerah guna melokalisir gangguan itu (agar tidak menyebar dan meluas), meredamnya (agar intensitasnya menurun) dan mencarikan solusi jangka pendek dan jangka panjangnya melalui proses negosiasi, mediasi, arbitrasi, maupun kalau 
perlu ajudikasi. 3). Tugas mengidentifikasi dan merevitalisasi kearifan lokal yang dapat mendukung kerukunan antar umat beragama. Menurut berbagai kajian dan penelitian Badan Litbang dan Diklat Kementerian Agama RI, setiap daerah ternyata telah memiliki sejumlah kearifan lokal, baik yang telah lama hidup maupun yang baru disepakati bersama, yang secara langsung atau tidak langsung mendukung kerukunan umat beragama. Sebagian kearifan lokal itu masing berjalan dan berfungsi dengan baik, tetapi sebagian lain nya tidak berfungsi lagi karena tidak sanggup menopang beban berat akibat laju kemajemukan penduduk dan kemajuan teknologi komunikasi dan informasi, sehingga perlu direvitalisasi secara terencana.

Demikianlah beberapa catatan tentang tugas dan sekaligus peran strategis FKUB dalam pemeliharaan kerukunan umat beragama dan kerukunan serta persatuan nasional dengan memperhatikan tiga lingkungan strategisnya yaitu kerangka landasan hukum yang ada, kebijakan pemeritah yang telah diberlakukan, dan dukungan sistem sosial dan partisipasi masyarakat.

Menurut Prof.Dr.H.M. Atho Mudzhar ia mengemukakan bahwa, Untuk melihat peran strategis FKUB dalam pemeliharaan kerukunan umat beragama dan persatuan nasional, khususnya dalam implementasi PBM Nomo 9 dan 8 Tahun 2006, paling kurang ada tiga lingkungan strategis yang saling terkait dan perlu dicermati, yaitu pertama mengenai landasan hukum bagi pemeliharaan kerukunan umat beragama, kedua mengenai kebijakan pemerintah dan sejumlah masalah dalam implementasinya, dan ketiga mengenai dukungan sistem masyarakat dan partisipasinya. Ketiga hal itu saling mengkondisikan dan menunjang upaya pemeliharaan kerukunan umat beragama yang pada gilirannya merupakan elemen

\section{IMPLEMENTASI KEBIJAKAN PEMERINTAH DALAM PEMELIHARAAN KERUKUNAN UMAT BERAGAMA.}

Ada dua kebijakan dasar pemerintah dalam pemeliharaan kerukunan umat beragama, yaitu pemberdayaan umat beragama dan pemberian ramburambu bagi upaya pemeliharaan kerukunan umat beragama. Salah satu kebijakan strategis yang telah diambil pemerintah dalam me mberikan ramburambu itu guna menjamin kebebasan beragama dan pemeliharaan kerukunan umat beragama ialah penerbitan Peraturan Bersama Mentri (PBM) Agama dan Menteri Dalam Negeri Nomor 9 dan 8 Tahun 2006 Tentang Pedoman Pelaksanaan Tugas Kepala Daerah/Wakil Kepala Daerah Dalam Pemeliharaan Kerukunan Umat Beragama, Pemberdayaan Forum Kerukunan Umat Beragama, dan Pendirian Rumah Ibadat. Sesuai judulnya, peraturan bersama atau biasa disebut PBM ini mengatur tiga hal, yaitu: pertama, apa tugas -tugas kepala daerah/wakil kepala daerah dalam pemeliharaan kerukunan umat 
beragama di daerahnya, termasuk bagaimana kaitan tugas-tugas itu dengan tugas kepala daerah sebagaimana diatur dalam UU Nomor 32 Tahun 2004 Tentang Pemerintahan Daerah; kedua, amanat kepada pemerintah daerah untuk mendorong masyarakatnya agar segera membentuk Forum Kerukunan Umat Beragama (FKUB) di setiap propinsi dan kabupaten/kota dan menfasilitasi FKUB itu agar dapat menjadi mitra pemerintah dan dapat menjalankan fungsinya sebagai katalisator aspirasi masyarakat; dan ketiga, memberikan rambu-rambu kepada pemerintah daerah dalam proses pemberian izin mendirikan bangunan yang akan digunakan sebagai rumah ibadat. Hal ketiga ini dipandang perlu diatur, karena kehadiran suatu rumah ibadat di tengah-tengah masyarakat, selain menjadi simbul keberadaan suatu umat atau masyarakat pengguna rumah ibadat itu, juga berdampak terhadap masyarakat sekitarnya dalam interaksi antar umat beragama.

\section{PARTISIPASI MASYARAKAT LUWU TIMUR DALAM PEMELIHARAAN KERUKUNAN UMAT BERAGAMA}

Bagian penting lain yang menentukan tingkat kerukunan umat beragama di Indonesia ialah sistem sosial Indonesia dan partisipasi masyarakatnya, khususnya para tokoh dan umat beragama itu sendiri. Kita mengetahui bahwa mayoritas penduduk Indonesia beragama Islam (88\%), selebihnya adalah Kristen Protestan (6\%), Katolik (3\%), Hindu (2\%), Budha, Konghucu dan lainnya (1\%). Fakta inilah yang kemudian mendorong sebagian orang menyatakan bahwa kerukunan beragama di Indonesia itu tergantung kepada kualitas hubungan antara pemeluk agama mayoritas (Islam) dan minoritas (lainnya). Pandangan seperti itu tidak salah seluruhnya, karena memang demikianlah fakta demografis itu secara nasional. Tetapi pandangan demikian itu terlalu menyederhanakan persoalan, minimal karena dua hal. Pertama, kerukunan umat beragama itu sesungguhnya terjadi di daerah, karena tidak ada sejengkal wilayahpun di negeri ini yang bukan merupakan bagian dari suatu daerah. Kedua, data demografis yang meletakan umat Islam sebagai mayoritas itu sesungguhnya hanya terjadi pada tingkat nasional dan sejumlah daerah, sedangkan pada sejumlah daerah lainnya gambarannya dapat jauh berbeda. Bahkan ada propinsi atau kabupaten/kota yang jumlah penduduk muslimnya hanya minoritas (10 - 15 persen), seperti di Bali, NTT, dan Papua. Hal ini terjadi karena adanya kantong-kantong konsentrasi penduduk pemeluk agama tertentu di suatu daerah. Penyebaran penduduk pemeluk agama yang tidak merata ini menimbulkan suatu mekanisme keseimbangan yang mendorong pemerintah pusat dan daerah untuk selalu mempertimbangan keragaman ini dalam setiap kebijakannya, baik kebijakan tentang kehidupan beragama maupun kebijakan publik pada umumnya. Inilah 


\section{2 | Kaharuddin, Muh. Darwis}

salah satu ciri sistem sosial Indonesia yang cenderung mendorong kerukunan umat beragama.

Faktor lain yang menguntungkan bagi upaya pemeliharaan kerukunan umat beragama di Indonesia ialah kepercayaan dan pengetahuan bahwa agama-agama yang sekarang berkembang di Indonesia ini, semuanya masuk ke Indonesia dengan jalan damai melalui migrasi penduduk, perdagangan, tarekat-tarekat sufi, dan kegiatan dakwah atau missionary. Tidak pernah ada perang agama di Indonesia. Kenyataan sejarah ini memperkuat pendapat bahwa hakekat ajaran agama-agama yang berkembang di Indonesia itu memang menghormati sesama pemeluk agama dan mendukung kerukunan antar umat beragama. Oleh sebab itu, jika terjadi sesuatu yang menyimpang dari prinsip umum ini maka semua pihak akan segera duduk bersama mencari solusinya. Semua pihak sepakat bahwa sekecil apapun konflik bernuansa agama yang terjadi, harus segera dilokalisir, diredam, dan dipadamkan untuk kemudian dibangun diatasnya jaringan persahabatan dan kerjasama.

Faktor lain lagi yang menjadi ciri sistem sosial Indonesia ialah adanya majlis-majlis agama pada tingkat Pusat, bahkan sebagiannya juga sampai tingkat daerah. Majelis-majelis ini merupakan mitra penting pemerintah, selain menjadi wahana penghubung diantara sesama majlis agama sendiri. Diantara masalahnya terkadang adalah karena sebagian majlis itu sendiri tidak dapat mengklaim mewakili seluruh lapisan umat beragama yang dipimpinnya, karena banyaknya variasi umat di dalamnya. Kita mengetahui didalam umat Islam yang diwakili MUI terdapat lebih dari 93 ormas Islam tingkat Pusat. Demikian juga di kalangan Kristen Protestan yang diwakili PGI terdapat 324 denominasi, sementara hanya sekitar 83 denominasi yang bergabung dengan PGI. Demkian juga dengan umat Hindu yang diwakili PHDI, umat Budha yang diwakili Walubi, dan umat Konghucu yang diwakili Matakin, sedikit banyak memiliki varian-varian juga di dalamnya. Sesungguhnya ini adalah masalah internal umat beragama, tetapi dapat berdampak kepada hubungan antar umat beragama karena jika terjadi hubungan buruk antar umat beragama di suatu tempat maka sesungguhnya seringkali yang terjadi ialah hubungan buruk antara keompok minoritas dalam suatu umat beragama dengan kelompok minoritas lain dalam umat beragama lainnya, katakanlah antara minoritas ektrim yang satu dan minorities ektrim lainnya. Karena itu majelis-majelis agama perlu terus berupaya untuk merangkul seluruh elemen umat yang ada di dalamnya dengan arif dan bijaksana. Wadah Musyawarah Antar Umat Beragama yang terdapat di tingkat Pusat juga perlu direvitalisasi dengan dukungan seperlunya dari pemerintah. 


\section{DUKUNGAN DAN KENDALA-KENDALA YANG DIALAMI FKUB DALAM MEWUJUDKAN HARMONISASI KEHIDUPAN BERAGAMA DI KABUPATEN LUWU TIMUR.}

Pada dasarnya FKUB Luwu Timur sudah lama terbentuk yang diprakarsai oleh masyarakat sendiri. Pada saatitu Forum ini bernama Forum Komunikasi umta Beragama sebelum masuk pada tahun 2016. Forum ini terbhentuk oleh akar rumput sendiri. Artinya forum ini disadari oleh masyarakat bahwwa sangat penting mewadai dan mengakomodir masyarakat Luwu Timur yang multis etnis, budaya, ras dan agama. Sejak itu berjalan dengan baik karena didukung oleh masyarakat. Setelah masuk tahun 2016 sampai sekarang berubah nama menjadi Forum Kerukunan Umat Beragama yang dikung dan dibentuk oleh pemerintah. Jadi mulai tahun 2016 Jadi mulai tahun 2016 Forum ini semakin kokoh dan kuat karena didukung oleh pemerintah.

Menurut bahwa FKUB Luwu Timur sangat didukung oleh Pemerintah Luwu Timur. Baik secara moril maupun material. Bentuk dukungan Pemerintah secara ril misalnya, selama ini sudah beberapa kali difasilitasi oleh pemerintah mengutus para pengurus FKUB mengikuti acara-acara FKUB di luar daerah. Baik berskalah nasional maupun Internasional. Selain itu bentuk dukungan Pemerintah terhadap FKUB di fasilitasi Bangunan kantor Permanen. Bahkan pemerintah mempasilitasi kendaraan mobil dinas, dan kedepan akan diusahakan gaji atau honor para pengurus FKUB Luwu Timur ini. Dari beberapa keterangan tersebut di atas dipahami bahwa FKUB Luwu Timur sangat respon oleh Pemerintah setempat, denga harapan bahwa FKUB adalah bahagian dari pemerintah dalam menjalan program pembangunan masyarakat Luwu Timur.

\section{PENUTUP}

Kabupaten Luwu Timur masyarakatnya sangat majemuk karena terdiri dari berbagai suku, ras, budaya dan agama. Tetapi kemajemukan itu juga masyarakat Luwu Timur sangat toleran Salah satu keunikan masyarakat Luwu Timur karena tidak saling mengusik antara satu dengan lainnya dalam berinteraksi sosial terutama dalam urusan yang terkait dengan keagamaan.

Forum Kerukunan Umat Beragama (FKUB) Luwu Timur sangat strategis dalam membina dan memelihara harmonisasi kerukunan hidup bermasyarakat, berbangsa dan bernegara, terutama dalam memelihara harmonisasi kerukunan hidup beragama, antar umat beragama, dan antar hidup beragama dengan Pemerintah. Harmonisasi dan kerukunan seperti itu terbangun karena salah satu komponen di dalamnya memiliki peran dan andil yang sangat besar adalah Forum Kerukunan Umat Beragama. Karena orang- 
orang yang terlibat dalam FKUB didengar dan ditokohkan oleh masyarakat. Sehingga jika ada masalah bisa terselesaikan dengan baik.

Pengembangan penelitian ini akan sangat menarik jika diteliti lebih jauh. Kiranya, untuk peneliti yang akan datang lebih mengkonsentrasikan diri pada upaya pelacakan secara geneologi- historis munculnya tradisi lokal dan agama di sebuah komunitas tersebut. Tentu saja, ini sebagai awal untuk sebuah perbandingan yang sifatnya analitis. Ramuan dialog dalam konteks kekinian tersebutharus mengapresiasi berbagai kearifan masyarakat lokal yang selama ini diabaikan dan terabaikan.

\section{DAFTAR PUSTAKA}

Bara, Ardias. Pengurus Forum Komunikasi Kerukunan Umat Beragama (FKUB) Luwu Timur. Wawancara. Kantor FKUB Luwu Timur, 2 Oktober 2018.

Budianto Arif, Kerukunan Umat Beragama (Studi Hubungan Pemeluk Islam dan Kristen di Relokasi Turgo Sleman Yogyakarta), (Yogyakarta: Ushuluddin), 2006.

Budianto Arif, Kerukunan Umat Beragama (Studi Hubungan Pemeluk Islam dan Kristen di Relokasi Turgo Sleman Yogyakarta), (Yogyakarta: Ushuluddin), 2006.

Bungin Burhan, Penelitiankualitatif. (Jakarta: Prenada Media Group), 2007.

D. A. Wila Huky, Pengantar Sosiologi (Surabaya: Usaha Nasional), 1986.

Direktorat Jenderal Nilai Budaya, Seni Dan Film. Pedoman Teknis Pemberdayaan Penghayat Kepercayaan terhadap Tuhan Yang Maha Esa (Jakarta: Departemen Kebudayaan dan Pariwisata), 2005.

Guntur, Muhammad. Kepala Kesbangpol Luwu Timur, 1 Oktober 2018.

H. Abu Bakar. Kepala Kementerian Agama Luwu Timur. Wawancara. Di Rumah Jabatan Kemeterian Agama Luwu Timur., 1 Oktober 2018.

H. Ardiansyah. Ketua Forum Kerukunan Umat Beragama Luwu Timur. Wawancara. Di Kantor FKUB Luwu Timur, 2 Oktober 2018.

H. Mando. Pengurus Forum Komunikasi Kerukunan Umat Beragama (FKUB) Luwu Timur. Wawancara. Kantor FKUB Luwu Timur, 2 Oktober 2018.

Harun. Kasi Bimas Kristen. Wawancara di ruang kerjanya Kantor Kemeterian Agama Luwu Timur, 20 September 2018.

K. J. Veeger, Realitas Sosial: Refleksi Filsafat Sosial atas Hubungan individu Masyarakat dalam Cakrawala Sejarah Sosiologi (Jakarta: Gramedia), 1993.

Lestari, Sri Puji. "Hubungan Antar Umat Beragama di Lingkungan Masyarakat Wihara Jina Dharma Sradha Desa Siraman Kecamatan Wonosari Kabupaten Gunung Kidul." Fakultas Ushuludin UIN Sunan Kalijaga, 2009. 
Lexy J. Moleong, Metodelogi Penelitian Kualitatif (Bandung: Remaja Rosdakarya, cet 13), 2000.

M Sastrapratedja, (ed). Manusia Multi Dimensional: Sebuah Renungan Filsafat (Jakarta: Gramedia), 1983.

Mardan. Staf Kemeterian Agama RI Kabupaten Luwu Timur. Wawancara,, 1 Oktober 2018.

Sapari Imam Asyari, Metodologi Penelitian Sosial Suatu Petunjuk Ringkas. (Surabaya: usaha nasional), 1981.

Soeryono Soekamto, Sosiologi Suatu Pengantar (Jakarta: Grafindo Persada), 1990

Sugiono. Memahami Penelitian Kualitatif, (bandung: ALFABET), 2005.

Sumarni S. Staf Kementerian Agama Luwu Timur. Wawancara., 1 Oktober 2018.

TEKAPE.com. Berita. Pengukuhan FKUB Luwu Timur, tekape.com.

Yoharis. Pendeta Agama Kristen Luwu Timur, Kantor Forum Komunikasi Umat Beragama Luwu Timur, 2 Oktober 2018. 